\title{
A Scanning Electron Microscopic Study of the Sacculus and Lagena in the Ears of Fifteen Species of Teleost Fishes
}

\author{
ARTHUR N. POPPER \\ Department of Zoology and Laboratory of Sensory Sciences, University of Hawail, Honolulu, \\ Hawaii 96822 and Kresge Hearing Research Institute, University of Michigan \\ Medical Center, Ann Arbor, Michigan 48109
}

\begin{abstract}
The ulstrastructure of the saccular and lagenar maculae were studied in 15 species of teleost fishes, using the scanning electron microscope. Particular attention was paid to hair cell orientation patterns, composition of the ciliary bundles on the hair cells, hair cell distributions, and supporting cell types. The hair cells on both otolithic organs are divided into several groups with all of the hair cells in each group oriented in the same direction. The posterior region of the saccular macula in all species had dorsally oriented hair cells on the dorsal half of the macula and ventrally oriented hair cells on the ventral half. The cells on the anterior end of the macula were oriented anteriorly and posteriorly, with the posterior group, in most species, being on the dorsal half of the anterior region of the macula. There was considerable inter-specific variation upon this basic pattern.

Inter-specific variation on the lagenar macula was considerably less than on the saccular macula. The basic pattern in all of the species includes one dorsal cell group and one ventral cell group.

There are four more-or-less discrete ciliary bundles, each varying in the relative size of the kinocilia and stereocilia. Intermediary forms were also observed, making it difficult to differentiate ciliary bundles in some instances. It was apparent, however, that several of the ciliary bundles were found in particular macular regions.
\end{abstract}

Interest in sound detection by teleost fishes has increased markedly over the past several decades (see reviews by Lowenstein, '71; Popper and Fay, '73; Tavolga, '71) and we now have a large body of data on detection mechanisms and capabilities, as well as on sound processing at several levels of the auditory systems. One area that is now of particular interest is the role of the inner ear in sound detection and processing (e.g., Enger, '63, '73; Enger et al., '73; Fay, '75; Fay and Popper, '74, '75; Furukawa and Ishi, '67; Sand, '74). However, the meaning of inner ear data, in terms of the function of the ear, is still unclear because of a lack of detailed knowledge of the morphology and ultrastructure of the auditory regions. These data are needed before a detailed analysis can be made of responses of the inner ear to sound stimulation, analytic capabilities of the ear (if any), and responses of the ear to sound source direction.

The teleost ear (fig. 1) consists of three semicircular canals and associated ampullary regions, and three otolith-containing vesicles. Two of these vesicles, the sacculus and lagena, are associated with audition (von Frisch, '36) in many species, although their specific contributions are still unknown (see Fay, '75; Furukawa and Ishii, '67).

Each otolith-containing vesicle has a sensory hair cell covered epithelium, or macula, in close proximity to a single dense calcareous otolith. The macula and otolith are separated by a thin otolithic membrane that may hold the otolith in place on the macula and provide mechanical coupling between the otolith and sensory hairs. The actual mechanisms for response to acoustic stimulation in the ear of 
Abbreviations
aa, anterior ampulla ap, posterior ampulla
ca, anterior canal
cp, posterior canal
k, kinocilium
m, microvilli
ms, saccular macula
mu, utricular macula
pl, lagena
s, sacculus
st, stereocilia

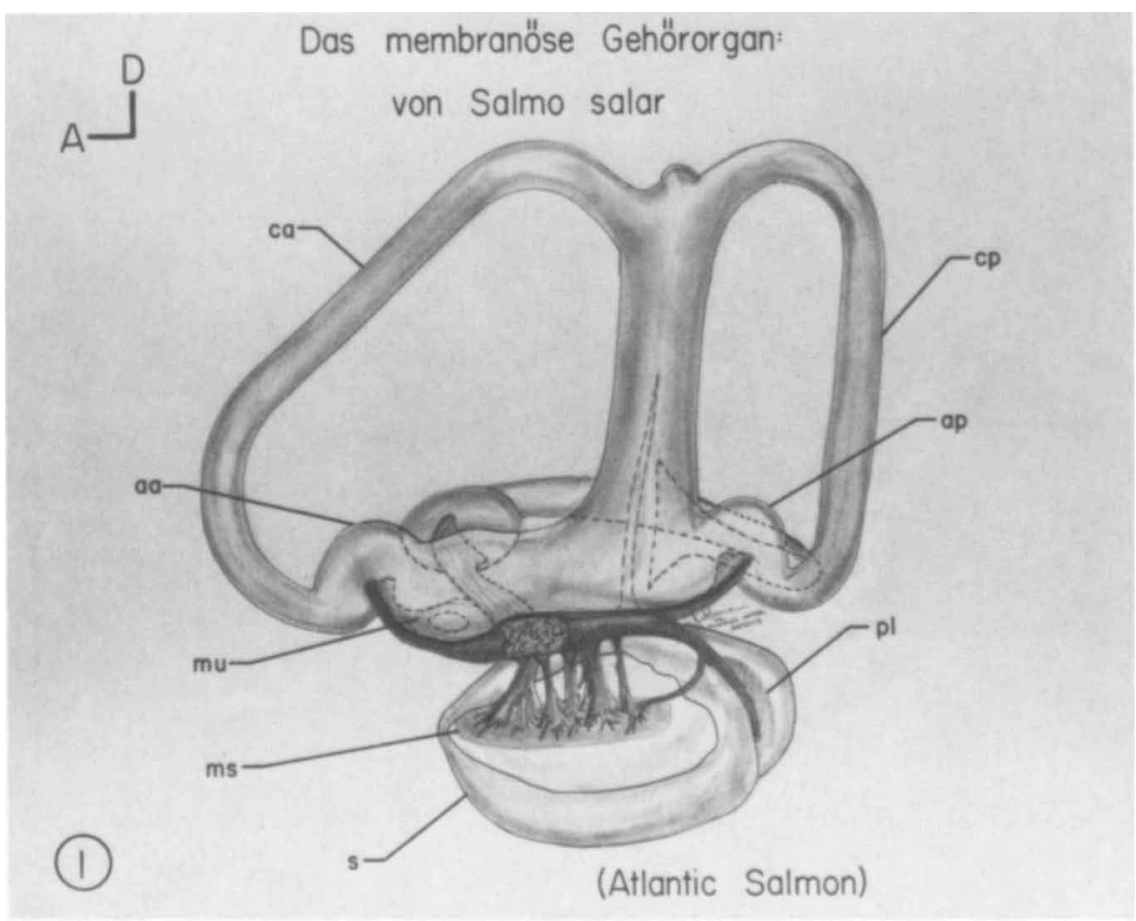

Fig. 1 Drawing (modified from Retzius, 1881 ) of a medial view of the right ear of Salmo salar.

fishes have not been directly studied, but it has been suggested that a sound field would cause the body of the fish (and the sensory macula) and the considerably denser otolith to move out of phase with one another, resulting in bending of the cilia on the hair cells (e.g., van Bergeijk, '67a; Wever, '69, '71).

The sensory hair cells consist of a cell body with a series of cilia on the apical surface. A number of workers have provided evidence that bending or shearing action on the cilia is responsible for the electrical response from the hair cells (e.g., Békésy, '60; Lowenstein and Wersäll, '59). Each ciliary (or hair) bundle consists of many (30-50 in fishes) stereocilia which are embedded in a thick cuticle that lies just under the apical cell membrane. A single, eccentrically placed kinocilium originates inside the cell at the basal body and penetrates the cell membrane. The kinocilium generally contains the typical $9+2$ filament pattern found in many metazoan flagella. Maximum hair cell depolarization occurs when shearing is along the cilia towards the kinocilium, and the response is inhibited when stimulation is reversed $180^{\circ}$. Stimulation off this axis gives a response whose level is a cosine function of the stimulus direction relative to the axis of maximum response (Flock, '65, '71).

Since the hair cells of the inner ear are functionally polarized, it is likely that this could significantly affect auditory capabilities and mechanisms. In fact, experiments have shown that the goldfish (Carassius auratus) sacculus has hair cells oriented in opposite directions, resulting in hair cell groups that respond to opposite phases (compression and rarefaction) of a stimulating signal (Furukawa and Ishii, '67; Piddington, '72). Recent 
work with perch (Perca fluviatilis) and haddock (Melanogrammus aeglefinus) has also demonstrated that different regions of the saccular macula have their best responses to stimulation in different directions (Enger et al., '73; Sand, '74), again suggesting that in the inner ear there is a functional polarization which may be involved with detection of sound source direction.

Data on hair cell orientation patterns in the inner ear of fishes show significant correlations with the physiological data. Furukawa and Ishii ('67), partially on the basis of the biphasic response to sound stimulation in the eighth nerve, hypothesized the presence of oppositely polarized hair cell groups in the goldfish sacculus. This hypothesis has been corroborated by Hama ('69) and Platt ('77), who have shown that most hair cells on the dorsal half of the saccular macula in goldfish are polarized dorsally (kinocilium on the dorsal side of the cells) while cells on the ventral half of the macula are polarized ventrally. $\mathrm{Bi}$. directional orientation has been reported for five species of catfish (Jenkins, '74), a group in the same superorder (Ostariophysi) as the goldfish, and for the burbot (Lota vulgaris) by Wersäll et al. ('65).

The data for the Ostariophysi and Lota closely resemble the bi-directional orientation pattern found in the saccules of tetrapods (e.g., Lewis and $\mathrm{Li}$, '75; Lindeman, '69; Spoendlin, '65) and the elasmobranch Raja clavata (Lowenstein et al,, '64). However, these data differ somewhat from recent data for a salmonid fish, the lake whitefish, Coregonus clupeaformis, (Popper, '76), the cod, Gadus morhua, (Dale, '76), and two species of flatfish, Pleuronectes platessa and Limanda limanda, (Jørgensen, '76). While the posterior saccule in Coregonus and the flatfish have dorsal and ventral hair cell groups, as in other species, the anterior-dorsal saccular quadrant has posteriorly oriented cells and the anterior-ventral quadrant has anteriorly oriented cells. The pattern in Gadus is similar except that horizontally oriented cells are also found on the posterior end of the saccular macula.

The data now available in the literature indicate that there is considerable interspecific variation in the hair cell orientation patterns of the sacculus (and to a lesser degree the lagena). However, the extent of this variation cannot yet be evaluated due to the small percent of teleost species for which data are available. Furthermore, while we have a limited idea regarding the functional significance of bi-directionality in the sacculus of the goldfish (Furukawa and Ishii, '67), it is difficult to extrapolate from this to other species. The present study is directed towards expanding our understanding of the ultrastructure of the teleost sacculus and lagena through a scanning electron microscopic (SEM) study of these organs in 15 species. While these data are not in any way representative of all (or even most) taxonomic groups, they do give a fairly comprehensive indication of the variation in ultrastructure and enable us to suggest some general ideas on the auditory function of the teleost ear.

\section{MATERIALS AND METHODS}

Data were obtained on the ultrastructure of the saccules and lagenae of 15 species of fish representing 10 families. The species were selected on the basis of availability, although attempts were made to use species that showed taxonomic and ecological variability and also to include a number of species for which sound detection and/or production data are available. Table 1 lists the species used as well as data on number of animals, sizes, and, where available, citations relating to acoustic behavior for these or related genera.

Animals were anesthetized with MS-222 (Sandoz) until they were immobile and then one of two procedures was followed. Animals from $5-20 \mathrm{~cm}$ in standard length were placed into a special dissection holder which permitted respiration during dissection, thus enabling a long dissection time. Specimens outside of this range were decapitated, since they did not fit the available holder. In all cases the cranium was opened dorsally, the brain removed by dissection and aspiration, and the ears exposed. The sacculi in most species were then opened dorso-laterally with a sharp blade, and chilled fixative ( $4 \%$ glutaraldehyde in S-collidine buffer for fresh water species; the same buffer with $4 \%$ sucrose for salt water animals) was perfused into the ears and cranial cavity for four to eight minutes. Fixation always started within three minutes of death in the decapitated animals. Most of the head tissue was then dissected away (keeping the ears moist at all times) and a block containing the ears was placed into a container of fixative for at least 48 hours with one fixative change about four to six hours after dissection. 
TABLE

Species used in studies of ultrastructure of the teleost ear

\begin{tabular}{|c|c|c|c|c|}
\hline Species & Family & $\begin{array}{l}\text { Standard length } \\
(\text { in } \mathrm{mm})\end{array}$ & $\begin{array}{l}\text { Number of } \\
\text { animals used }\end{array}$ & $\begin{array}{l}\text { References on sound production (P) } \\
\text { or sound detection (D) }\end{array}$ \\
\hline Salmo salar & Salmonidae & $240-260$ & 4 & Van der Walker, '67 (D) ${ }^{\prime}$ \\
\hline Salvelinus namaycus & Salmonidae & $240-260$ & 5 & Van der Walker, '67 (D) ' \\
\hline Ceratoscopelus warmingi & Myctophidae & $20 \cdot 30$ & 2 & Marshall, '67 (P,D) 1 \\
\hline Diaphus brachycephalus & Myctophidae & $20-30$ & 2 & Marshall, '67 (P,D) ${ }^{1}$ \\
\hline Lampanyctus sp. & Myctophidae & $20 \cdot 30$ & 2 & Marshall, '67 (P,D) ${ }^{1}$ \\
\hline Adioryx xantherythrus & Holocentridae & $60-70$ & 5 & $\begin{array}{l}\text { Popper et al., '73 (D) }{ }^{1} \text {; } \\
\text { Salmon, '67 (P) '; Tavolga and } \\
\text { Wodinsky, ' } 63 \text { (D) }{ }^{1} \text {; Nelson, ' } 55 \text { (D) } 1\end{array}$ \\
\hline Myripristis berndti & Holocentridae & $60-70$ & 2 & $\begin{array}{l}\text { Popper et al.,' } 73 \text { (D); Salmon, } \\
\text { '67 (P); Tavolga and Wodinsky, } \\
\text { '63 (D) '; Nelson, '55 (D) }{ }^{1}\end{array}$ \\
\hline Aequidens pulcher & Cichlidae & $40-50$ & 3 & $\begin{array}{l}\text { Myrberg et al., '65 (P) }{ }^{1} \text {; } \\
\text { Tavolga,' } 74 \text { (D) }{ }^{1} ; \text { Fay and } \\
\text { Popper, '75 (D) }{ }^{1}\end{array}$ \\
\hline Tilapia macrocephala & Cichlidae & $40-50$ & 5 & $\begin{array}{l}\text { Myrberg et al., '65 (P) '; Tavolga, } \\
\text { '74 (D); Fay and Popper, '75 (D) }\end{array}$ \\
\hline Chaetodon miliaris & Chaetodontidae & $40-50$ & 3 & \\
\hline Dascyllus albisella & Pomocentridae & $40 \cdot 50$ & 3 & Myrberg and Spires, '72 (P) ${ }^{1}$ \\
\hline Lagodon rhomboides & Sparidae & $40-50$ & 3 & $\begin{array}{l}\text { Caldwell and Caldwell, '67 (P), } \\
\text { Tavolga,' } 74 \text { (D) }\end{array}$ \\
\hline Lepomis macrochirus & Centrarchidae & $40-50$ & 5 & Gerald, '71 (P) \\
\hline Percaflavescens & Percidae & 40.50 & 3 & Sand, '74(D) \\
\hline Xenotoca eiseni & Goodeidae & $20-30$ & 5 & \\
\hline
\end{tabular}

Data for species studied with the SEM or a closely related species.

After fixation the tissue was washed in Millonig's buffer. The ears were then dis. sected from the large block of tissue, stained with $1 \%$ osmium tetroxide for one hour, and moved to $70 \%$ ethanol for storage and further dissection. Final preparation for the SEM involved opening the membranous otolithic capsules and gently pulling the otoliths away from the sensory maculae. In many cases the otolithic membrane came away from the sensory epithelia along with the otolith, thus providing data on the extent of the membrane in relation to the otolith and macula. In some cases the otolithic membrane remained on the macula and then it was either removed by dissection or with a cleaning procedure (see below), or left in place for investigation of the relationship between the two structures.

After dissection the tissue was $\mathrm{CO}_{2}$-criticalpoint-dried, using amyl acetate as the intermediary fluid, placed on an aluminum stub, coated with about $150 \AA$ thickness of gold, and viewed with a JEOL JSM-U3 scanning electron microscope.

In order to study hair cell orientation it was necessary to determine the position of the kinocilium relative to the stereocilia but this was sometimes difficult when the cilia were in place since they could be bent or rotated during fixation. In addition, excess otolithic membrane could remain on the macula, even after careful dissection, interfering with determination of hair cell orientation. In order to eliminate these problems, some of the osmium stained specimens from each species were placed in an ultrasonic cleaner (Corwin, '77) for 30 seconds to 2 minutes (the length of time varied for each species and was determined by trial and error). This treatment removed the excess otolithic membrane and often "blew" the cilia off the sensory cells while leaving the microvilli in place on the support cells. In these cells the bases of the stereocilia were visible in the cuticle and showed up as shallow pits or as white spots while the kinocilium was represented either by a thicker stub or, in most cases, by a deep hole in the cell membrane where the $\mathrm{ki}$ nocilium penetrated the cell to the basal body. It was also found that sonication for shorter periods of time (10-20 seconds) in many species would frequently remove most of the otolithic membrane but leave the cilia intact, thus permitting studies of cilia structure.

Hair cell orientation patterns were determined in several specimens of each species whenever a sufficient number of specimens were available. Low power photographs were taken and orientation of hair cells in each region of the macula, as observed on the SEM, 
were noted on the photos. Cracks and small piece of "debris" on the tissue were used as landmarks in the mapping procedure.

\section{RESULTS}

There were many similarities in inner ear morphology and ultrastructure in most of the species studied. The features held in common will be described first and then followed with data from each of the species to give variations from the general pattern.

The sacculus and lagena are found in the cranial cavity at the level of the medulla. The sacculi in the species studied are partially recessed in the floor of the cranial cavity with the posterior end of the sacculus and all of the lagena covered by overlying bone. In some species, such as the two salmonids and Perca, the membranous labyrinth lies loosely in the bony chamber while in other species, such as the cichlids, the sacculus and lagena were difficult to remove since the anterior ends of the sacculus are partially covered by overlying bone.

The most distinct condition was found in the holocentrids where the membranous laby. rinth appeared to be "tied" to the bony walls of the cranial depression. In both species the most anterior tip of the sacculus was also covered by bone and the membranous chamber appeared to be physically connected to the bone at this point. Consequently, it was essentially impossible to remove the membranous labyrinth intact, and it had to be studied in situ before dissection.

The precise position of the lagena varies with respect to the sacculus, but it is always found in the dorsal-posterior quadrant of the saccular chamber. The continuity between the sacculus and lagena vary. In salmonids the two structures are in a single enlarged chamber (see fig. 1 and Popper, '76), while in most other species there is only a small opening between two discrete chambers.

The sacculi in all species were oriented at an angle to one another with the anterior edges spread further apart than the posterior so that the saccules, when viewed from above, had a V-like appearance.

\section{Otolith and otolithic membrane}

A single dense calcareous otolith lies close to the sensory macula in both sacculus and lagena. The saccular otolith (sagitta) has a deep medial groove into which the macula fits. The lagenar otolith is slightly smaller than the macula and it often has a shallow indentation for the macula. In many of the species (with the exception of the salmonids and possibly the myctophids) there is an anterior hook-like lateral projection that swings around the anterior edge of the lagenar macula into an area containing non-sensory epithelium.

The size of the otoliths, relative to the volume of the membranous labyrinth, varies in different species. The lagenar otolith never fills the membranous chamber, and in most instances it only covers the ventral threefourths to five-sixths of the macula sensory region. There is generally a large space lateral to the otolith. The extent to which the sagitta fills the saccular chamber is considerably more variable. In several species, including the cichlids, holocentrids and Chaetodon, the otolith almost totally fills the chamber and touches the lateral walls. This is contrasted to the condition in salmonids where the otolith fills perhaps $75 \%$ of the labyrinth volume. The most extreme condition observed is in one species of myctophid (Lampanyctus sp.) where the otolith only fills about $25 \%$ of the saccular chamber.

A thin otolithic membrane lies between the otolith and each macula and is a continuous sheet over the whole macula, even in regions not covered by the otolith. While detailed investigations of the otolithic membrane were not made, it was clear that membrane fixed for use in the SEM from several species (e.g., Adioryx, salmonids, myctophids) have a series of "holes." In several instances a single ciliary bundle could be seen in each of these holes (fig. 2).

\section{Hair cell orientation patterns: sacculus}

In the following discussion the orientation of the hair cells will be described relative to the long axis of the appropriate macula rather than the axes of the fish. This is necessary since the otolithic regions are not necessarily oriented in the same way in different species and, as a result, discussion of orientation relative to the fishes' axes would be confusing in inter-specific comparisons of orientation patterns. However, the general position of each of the macular regions in the ear is similar to the same region shown in figure 1.

In each species the saccular hair cells are divided into four discrete orientation "groups" (e.g., fig. 3) with all hair cells in each group oriented in the same direction. In all 
cases the posterior region of the macula has a dorsally-oriented hair cell group on the dorsal half of the macula and a ventrally-oriented group on the ventral half of the macula (fig. 3 ). These cells generally change orientation to follow macula curvatures.

Two orientation groups are found on the anterior region of the saccular macula and these show most of the variation in orientation patterns in the species I have studied. In most species the cells on the dorsal-anterior quadrant are oriented posteriorly and in the ventral-anterior quadrant oriented anteriorly (e.g., fig. 3; for exceptions see discussion of myctophids and Myripristis).

The transitions between groups of hair cells vary to some degree, although in all species the change from dorsal to ventral groups or from anterior to posterior groups occurs over several (generally two to three "rows" 1 containing hair cells from both orientation groups. Transitions from posterior to dorsal groups and from anterior to ventral groups are somewhat more complex in many species and may occur over five to 10 hair cell rows in some species (e.g., salmonids) or in one or two rows in others (myctophids). Where multiple transition rows are found, the cells are often oriented at approximately $45^{\circ}$ between the orientation patterns of the two major groups that they separate.

\section{Lagena hair cell orientation patterns}

For reasons that are not clear it was considerably more difficult to prepare totally satisfactory lagenar maculae of several of the species than it was to prepare saccular material. In these species (e.g., cichlids and holocentrids) various fragments of "debris," such as otolithic membrane, remained firmly attached to the macula and no amount of dissection and/or ultrasonic cleaning could remove the tissue without destroying the sensory epithelium. However, in most cases it was possible to get a composite picture of the lagena orientation patterns by studying a number of organs, each having complete hair cell patterns in one or more regions.

Considerably less inter-specific variation in hair cell orientation pattern is found in the lagena than the sacculus. I have found three distinct, but similar lagena patterns distributed among the species (except for the one myctophid) for which lagena material was available. In all species the hair cells on the anterior side of the lagenar macula are oriented dorsally, while the cells on the posterior side are oriented ventrally. There may be up to $20 \%$ variability in intra-group hair cell orientation. This variation is most noticeable at the transition zone between dorsal and ventral groups where the cells may be oriented almost directly towards the opposite cell group (also see Popper, '76).

The orientation patterns in the three lagena types are basically similar (figs. 4-6). One type, tentatively called type A (fig. 4) was previously described for Coregonus (Popper, '76) and the same pattern is found in the two salmonids reported here. The lower two-thirds of this macula is of relatively constant width, while the top third (the dorsal "arm") is somewhat narrower. The hair cells on the lower region are all oriented relative to the fish's dorsal-ventral axis and stay oriented in the same direction even as the macula curves. The cells in the dorsal arm, however, are oriented parallel to the macula curvature. There is also less inter-cell orientation variability than in the lower macula region, and transition zone cells are oriented in the same direction as the rest of the cells in each group. While the dorsally oriented cell group is contiguous from the ventral region into the dorsal arm of the macula, the ventrally oriented cells terminate just below the start of the arm and then "start up" again in the arm. The otolith associated with the type A lagena covers the lower macula region, although the otolithic membrane continues into the dorsal arm covering all of the hair cell regions.

The type B macula (fig. 5) has a wide ventral area and a narrow dorsal arm. The cells on the ventral half of the macula turn along with the margins and face almost perpendicular to the cells of the same group on the dorsal half of the macula. Furthermore, the ventral group may fill in below the dorsal cells. Transition between dorsal and ventral groups is similar to the transition groups in type A lagena. The otolith has an anterior lateral hook lying over non-sensory epithelial cells.

The type C macula (fig. 6) has cells oriented dorsally and ventrally, as in the other lagenae, but both cell groups tend to curve as the macula curves. Transition between cell groups is similar throughout the macula with

'This word is used nominally and. in fact, hair cells in all of the sensory regions of the teleost ear are not aligned in discrete rows. 


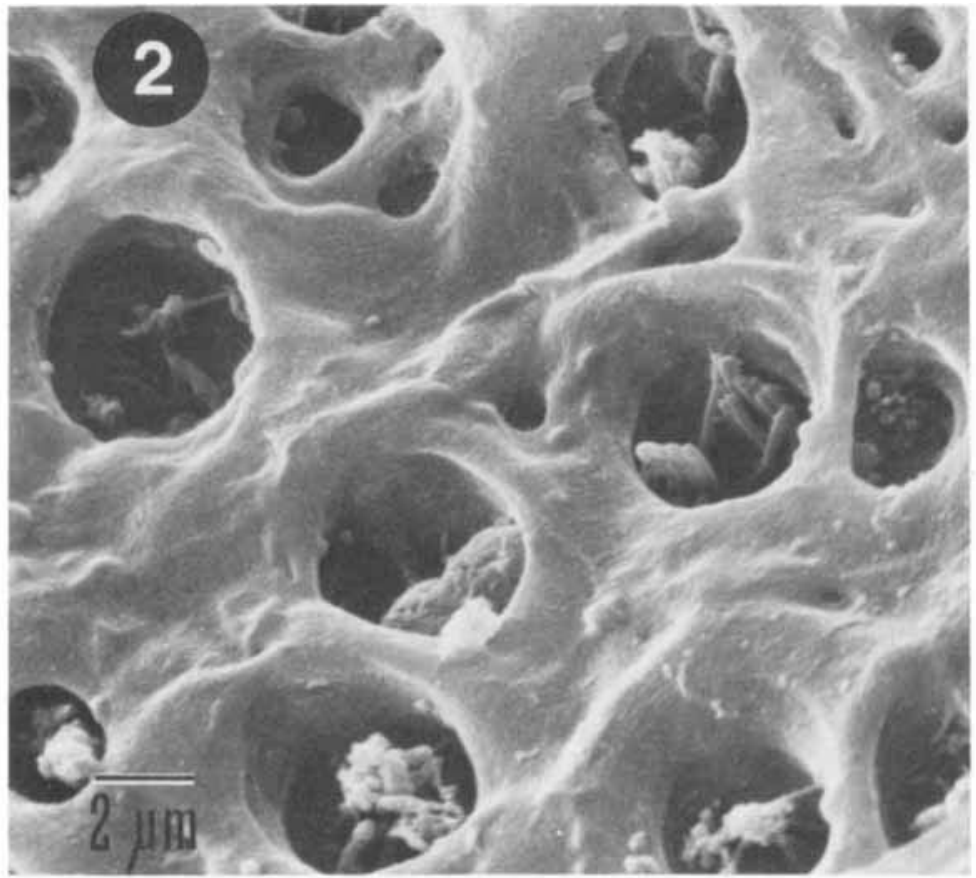

Fig. 2 SEM of the otolithic membrane on the saccular macula of Adioryx showing holes containing the ciliary bundles. The texture of the otolithic membrane may not indicate its true nature, since I have no idea of the effect of the fixation process on the membrane.

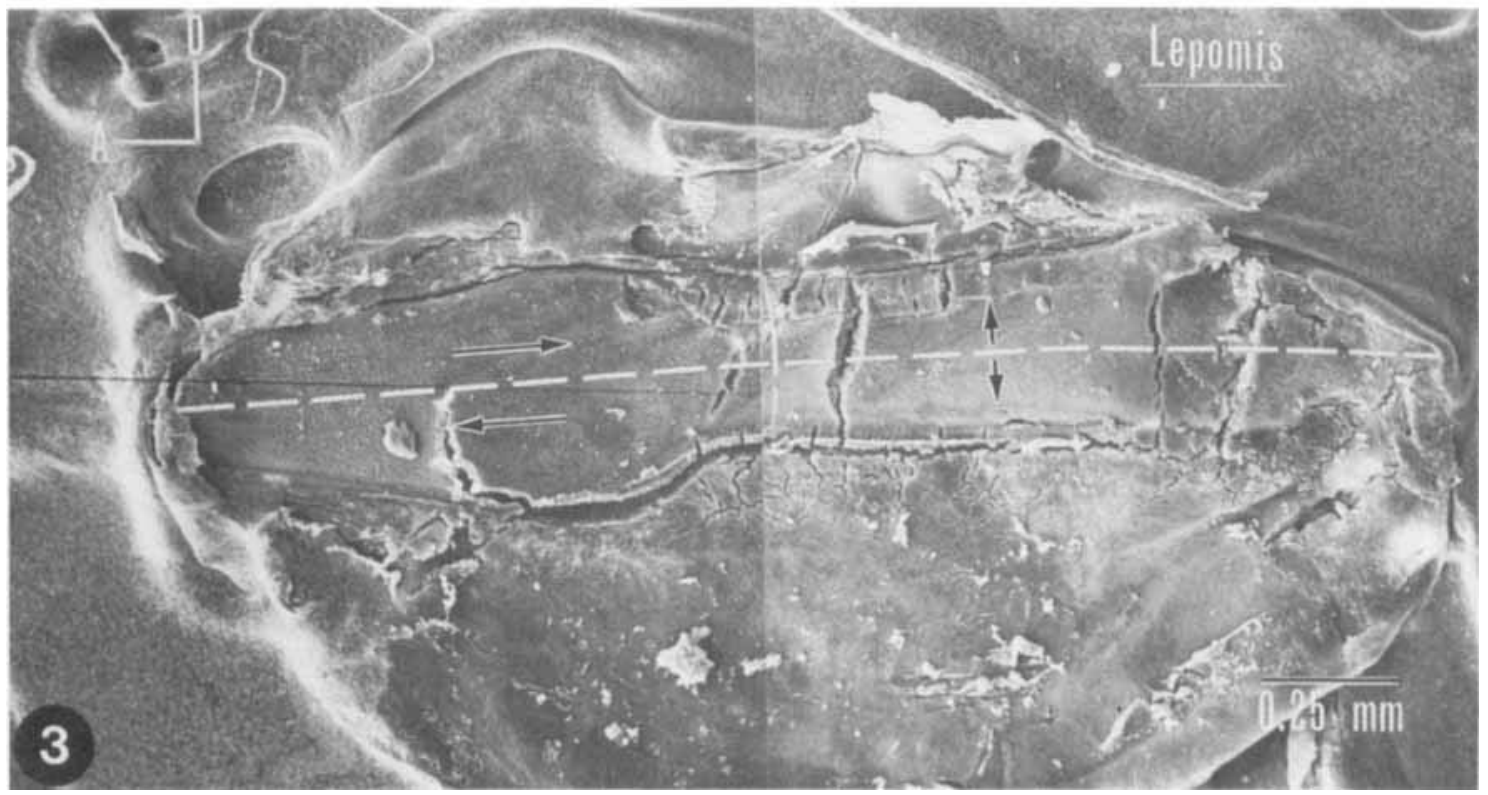

Fig. 3 SEM of the whole saccular macula from Leopomis macrochirus showing the orientation of the hair cells in each of the macula regions. In this and the following illustrations the tips of the arrows indicate the side of the hair cells on which the kinocilium is located in this region. 


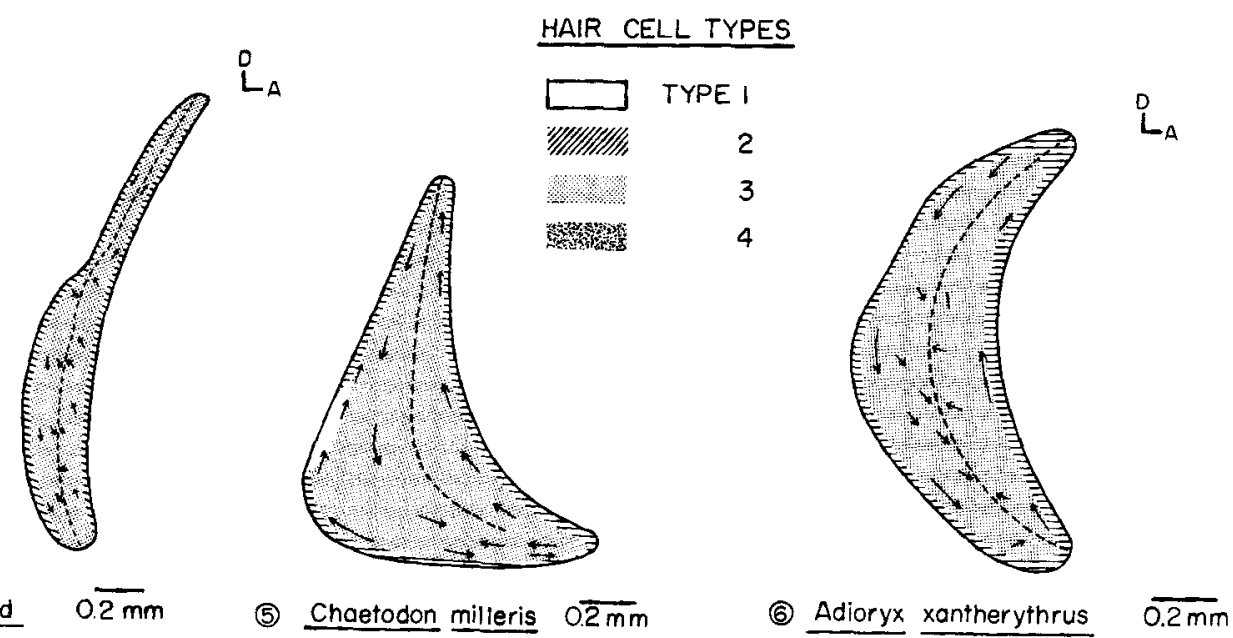

(4) Salmonid $0 \overline{2 \mathrm{~mm}}$

(5) Chaetodon milleris $0 \overline{2 \mathrm{~mm}}$

Adioryx xantherythrus

$\overline{0.2 \mathrm{~mm}}$

Fig. 4 Hair cell orientation patterns and ciliary bundle distribution patterns on the lagenar macula of Salmo and Salvelinus. The arrows point to the direction of orientation of the kinocilia on the hair cells in each region and the dashed lines shows the transition zones between major hair cell orientation groups. The distributions of the various ciliary bundle types are indicated in the figures. The key of ciliary bundle types is for this and all subsequent figures.

Fig. 5 Lagenar macula of Chaetodon. Explanation as in figure 4.

Fig. 6 Lagenar macula of Adioryx. Explanation as in figure 4.

cells close to the transition zone oriented towards the opposite cell group. The otolith covers all but the top one-sixth of the macula and has at the anterior end a laterally-directed "hook" which bends around the anterior edge of the macula and lies over non-sensory epithelial cells. No otolithic membrane was associated with the area under the hook.

\section{Hair cell ciliary bundles}

Several different types of ciliary bundles were found on the hair cells and each appears to be dominant in specific macula areas. However, while these types are fairly discrete, there are intermediary forms making it difficult, at times, to discriminate between various bundles. The most common ciliary bundle, to be called $\mathrm{F}^{2}{ }^{2}$ (fig. 7), consists of a series of short, graded stereocilia, and a kinocilium that is 1.1 to 2.0 times longer than the longest stereocilia. The cells containing F1 ciliary bundles are widely distributed on the saccular macula of most species. Type F1 bundles are also found in the lagenae of several species as well as in the central region of the utricular macula (Popper, unpublished).

The type F2 ciliary bundle has short graded or non-graded stereocilia and a kinocilium that is 3 or more time longer than the longest stereocilia (fig. 8). The type F2 bundle is frequently found on cells located at the borders of the sacculus and lagena and may consist of one to ten "rows" which then merge in to other cell types (fig. 9). In some instances the F2 bundle is also found on cells making up larger regions, as seen in both cichlids (fig. 8).

The type F3 ciliary bundle has a long kinocilium, several stereocilia of almost equal length, and several shorter stereocilia (fig. 10). The distribution of the type F3 ciliary bundle is less well defined than types F1 and F2, but it is often found on the lagena, in areas not covered by the otolith. It is also the dominant ciliary bundle found on the myctophid sacculus.

In some instances a type $\mathrm{F} 4$ ciliary bundle has been found. This closely resembles type F1 except that the cilia are all several times longer than those in the F1 bundle. No specific distribution pattern was found for the type F4 cilia and this may be partly due to the fact that these closely resemble type F1.

\section{Supporting cells}

The sensory hair cells in all maculae were surrounded by several microvilli-covered supporting cells. Several different types of sup. porting cells were found in the various species

\footnotetext{
2. Various authors have been using identical systems to designate cilia patterns in different species and this could eventually lead to confusion as more patterns are discovered. Tentatively I am using the designation $F$ for the patterns found in fishes to eliminate some confusion in later discussions.
} 

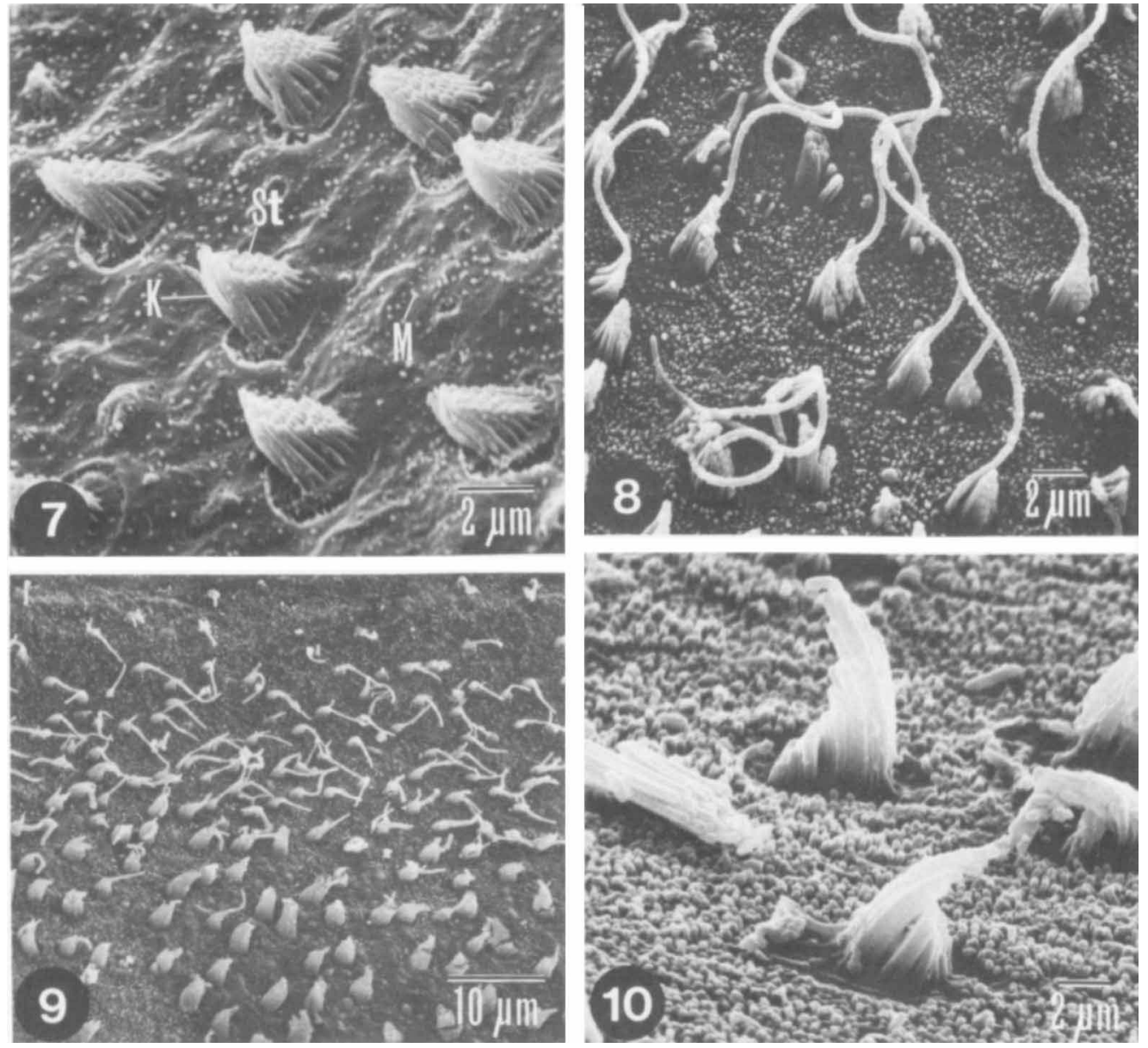

Fig. 7 SEM from Adioryx showing type F1 ciliary bundles all oriented in the same direction. Microvilli on the supporting cells between the hair cell bundles are typical of those in most of the sensory regions.

Fig. 8 SEM from Aequidens showing a group of type F2 ciliary bundles, found in the ventral portion of the saccular macula of the cichlids (see fig. 19). All cells in this region are oriented anteriorly.

Fig. 9 SEM of a border region in the saccular macula of Tilapia showing type F2 ciliary bundle at the macula border. More medially these grade into the type F1 ciliary bundles.

Fig. 10 Type F3 ciliary bundle from Lampanyctus showing opposite polarization of the border between posteriorly and anteriorly oriented hair cells.

studied. The most common cell was found on the sensory maculae ( $\mathrm{X}$ in fig. 11) and contained a relatively even distribution of short microvilli (also figs. 7-10). A second type of supporting or perimacular cell ( $\mathrm{Y}$ in fig. 11), generally found in regions outside of the macula, has a relatively featureless surface except for a ring of microvilli around the circumference of the cell. A third type of supporting cell ( $\mathrm{Z}$ in fig. 12) has a bulbous appearance (which is conceivably a fixation artifact) and a high microvilli density. This cell is out- side of the sensory region. It was also found interspersed with regular supporting cells in the central sensory region on the saccular macula in Myripristis.

The areas outside of the lagena and saccular sensory regions also have extensive areas of non-sensory epithelium which generally have high microvilli density (fig. 11). Many of these cells have a single central cilium which was somewhat longer than the other microvilli. This type of cilium was not found in supporting cells within the sensory region, 

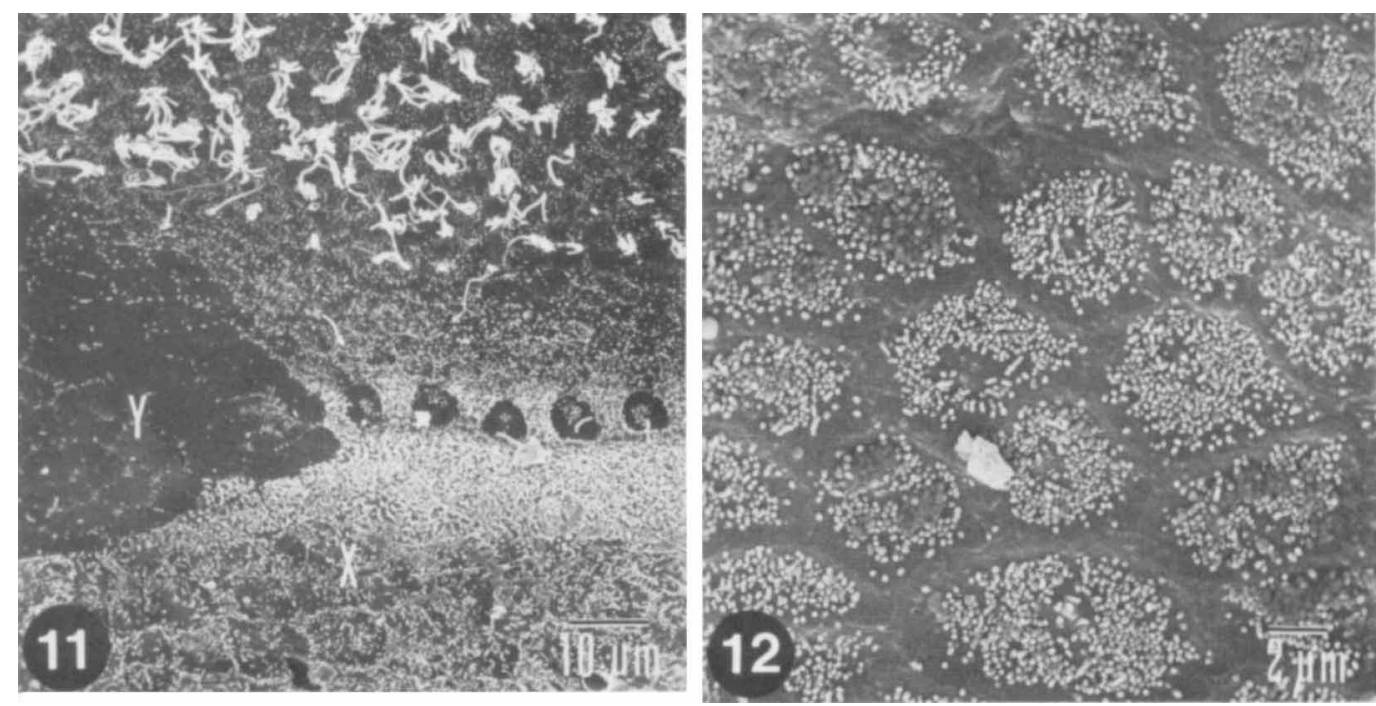

Fig. 11 SEM from Ceratoscopelus showing two types of supporting cells in a region of the macula just ventral to the sensory region. One cell ( $\mathrm{X}$ ) has an even distribution of microvilli, while another cell (Y) has an almost featureless surface.

Fig. 12 A third type of supporting cell from Myripristis having a high microvilli density.

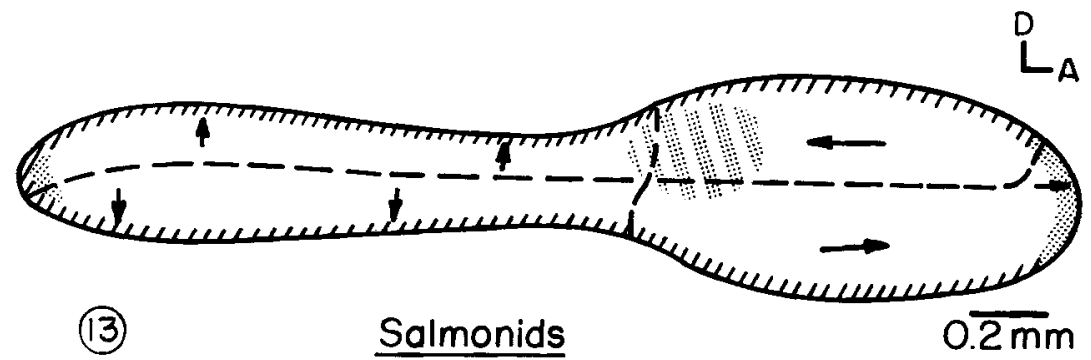

Fig. 13 Saccular macula hair cell orientation pattern and hair cell distribution patterns for both salmonid species. For explanation of figure and cell distribution pattern see figure 4 .

but similar cells have been reported in the sensory region of the lagena of the goldfish and loach (Saito, '73).

\section{Hair cell orientation patterns}

In the following discussion the data will supplement the general descriptions already given.

\section{a. Salmo and Salvelinus (fig. 13)}

The sacculus and lagena patterns in these salmonids closely resemble the organs in the lake whitefish (Popper, '76). The sacculus has four orientation groups with the anterior-oriented group covering the ventral-anterior quadrant as well as several rows on the ante- rior tip of the macula. The sacculus and lagena in both species have type F2 ciliary bundles on the borders. Type F3 ciliary bundles are found on cells located on the dorsal arm of the lagena and there is a small region where these bundles are found on the anterior and posterior tips of the sacculus. The sagitta covers all but the anterior and posterior tips of the macula.

\section{b. Chaetodon and Dascyllus (figs. 14, 15)}

The saccular hair cell orientation patterns are similar in these Hawaiian reef species. The sagitta in both species covers the whole macula and fills the membranous chamber. The posterior two-thirds of each macula lies 
on the vertical plane of the fish, while the anterior-dorsal quadrant bends laterally so that it is about $30^{\circ}$ from the fish's vertical plane. The hair cells are organized into four quadrants, although the most anterior tip of the macula has cells that are oriented posteriorly.

Both species have a type B lagena. Chaetodon, however, has one to three rows of dorsally oriented hair cells on the ventral and posterior margin of the macula (fig. 6), even though the bulk of the cells in these regions were oriented ventrally. The dorsal cells end about three-fourths of the way up the posterior edge of the macula. These cells were present in lagenae in the three specimens I studied but in no other species. The marginal ciliary bundles on the lagena macula (as on the sacculus) of both species are type F2 with the bulk of each lagena being covered by type F3 bundles.

\section{c. Perca, Lepomis, and Lagodon} (figs. 16-18)

The sacculi in these species are basically similar to one another with the maculae divided into four quadrants. The anterior 33\% of the macula in Perca (an area not covered by the otolith) is covered with type F3 ciliary bundles while this area has F1 bundles in the other species. The posterior end of the sacculus in Lagodon curves ventrally and its anterior dorsal quadrant bends laterally about $30 \%$, much as in Chaetodon and Dascyllus.

The lagena in Lagedon is type C while in Lepomis and Perca it is type B. F2 ciliary bundles are found on the marginal cells in all lagenae. Most of the cells in Lagodon have type F1 ciliary bundles except for about ten rows on the anterior margin of the macula which are type F3. Most of the ciliary bundles on the lagena in Lepomis are type F3 while those on the dorsal arm of Lagodon are F3 with the rest of the lagena being type F2.

\section{d. Tilapia and Aequidens (fig. 19)}

The ears in both cichlids are very similar to one another. The saccular maculae lie parallel to the vertical plane in both species and they are completely covered by the sagitta. The saccular hair cells are in the four basic orien. tation groups, although the anterior-oriented cells move into, and fill, a region that would normally be occupied by posterior-oriented cells. The cells just dorsal and ventral to the transition zone in this region are oriented parallel to the transition zone. In addition to marginal F2 ciliary bundles, there is a small region of type $\mathrm{F} 3$ ciliary bundles at the poste-
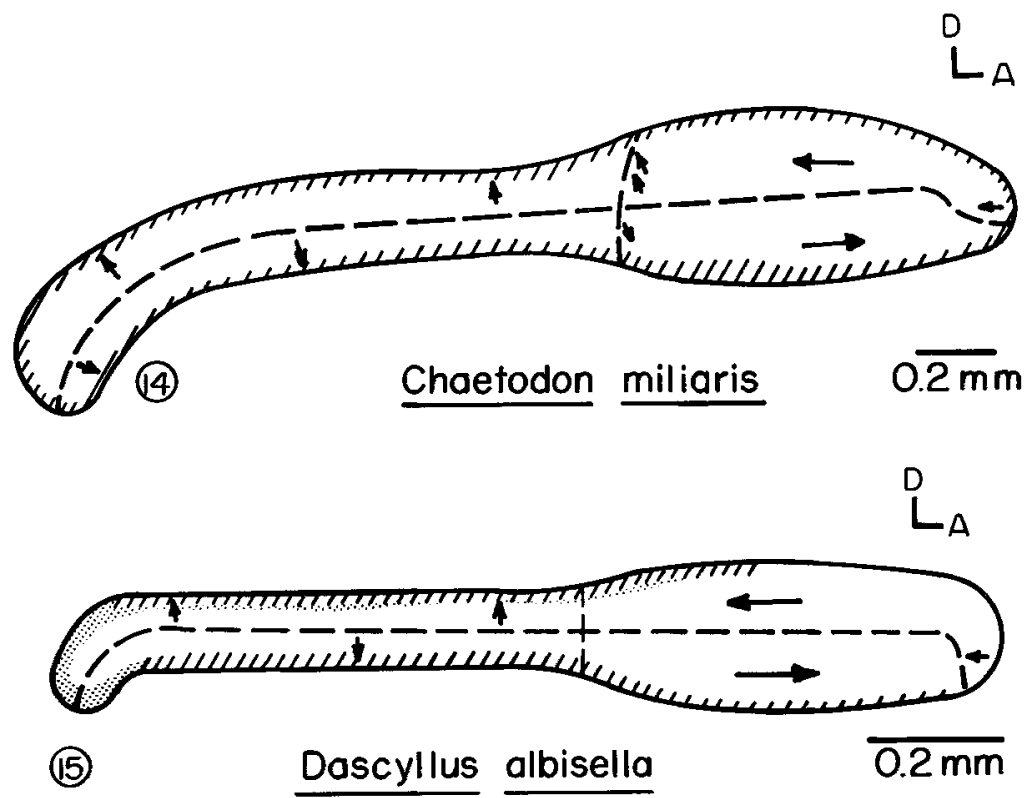

Fig. 14 Saccular macula of Chaetodon. For explanations see figure 4.

Fig. 15 Saccular macula of Dascyllus. For explanations see figure 4. 

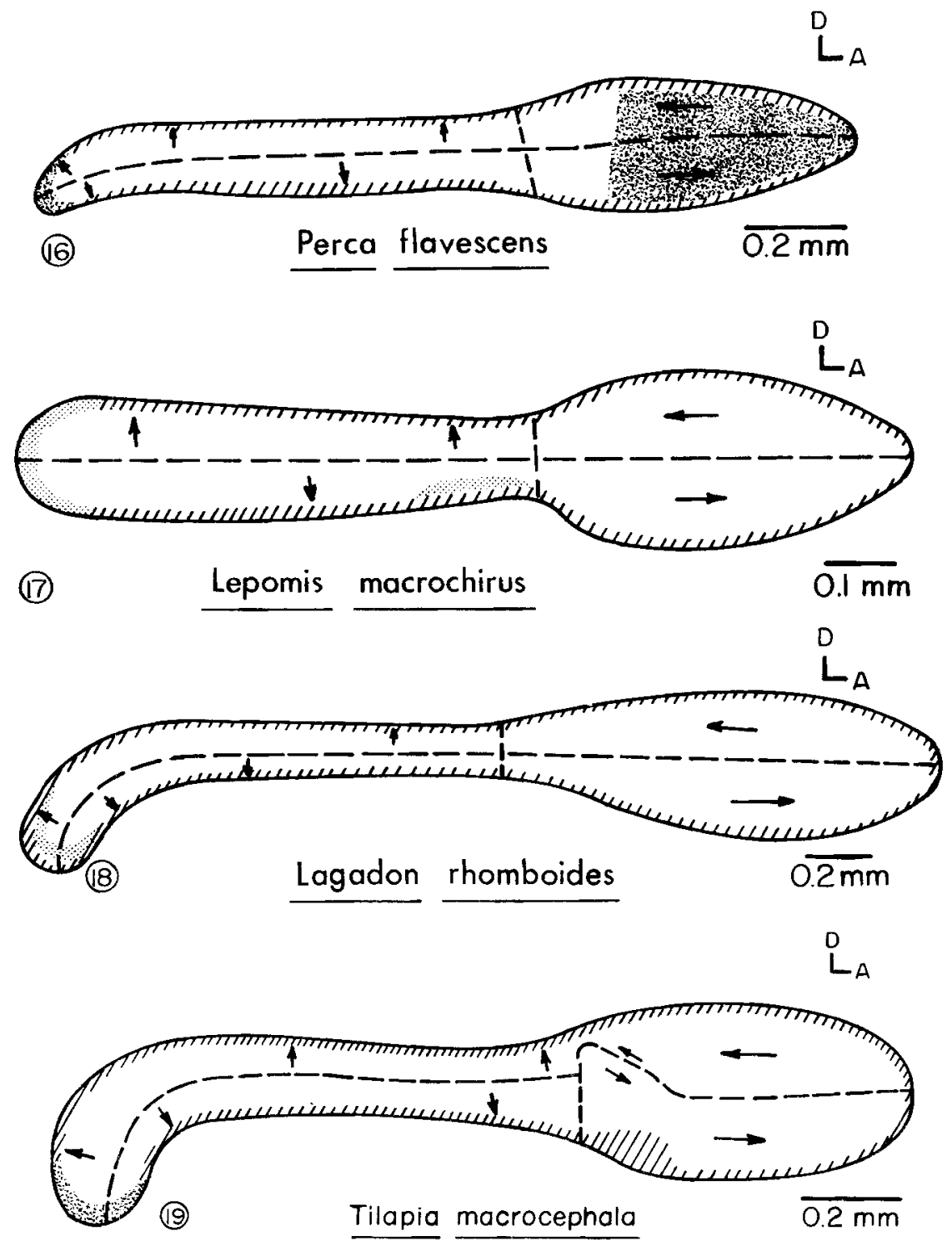

Fig. 16 Saccular macula of Perca. For explanations see figure 4.

Fig. 17 Saccular macula of Lepomis. For explanations see figure 4.

Fig. 18 Saccular macula of Lagodon. For explanations see figure 4

Fig. 19 Saccular macula of Tilapia. For explanations see figure 4.

rior tip of the maculae. Marginal F2 cells also cover a small region on the ventral-anterior region of the maculae (fig. 19).

Both species have type $B$ lagenae. Most of the ciliary bundles are type F1 except for a series of type $\mathrm{F} 3$ in the ventral posterior margin of the maculae. The lagena itself is oriented at almost a $60^{\circ}$ angle to the posterior region of the sacculus.

\section{e. Xenotoca (fig. 20)}

This Mexican molly is the only species studied that did not have a noticeable widening of the anterior end of the saccular macula. 

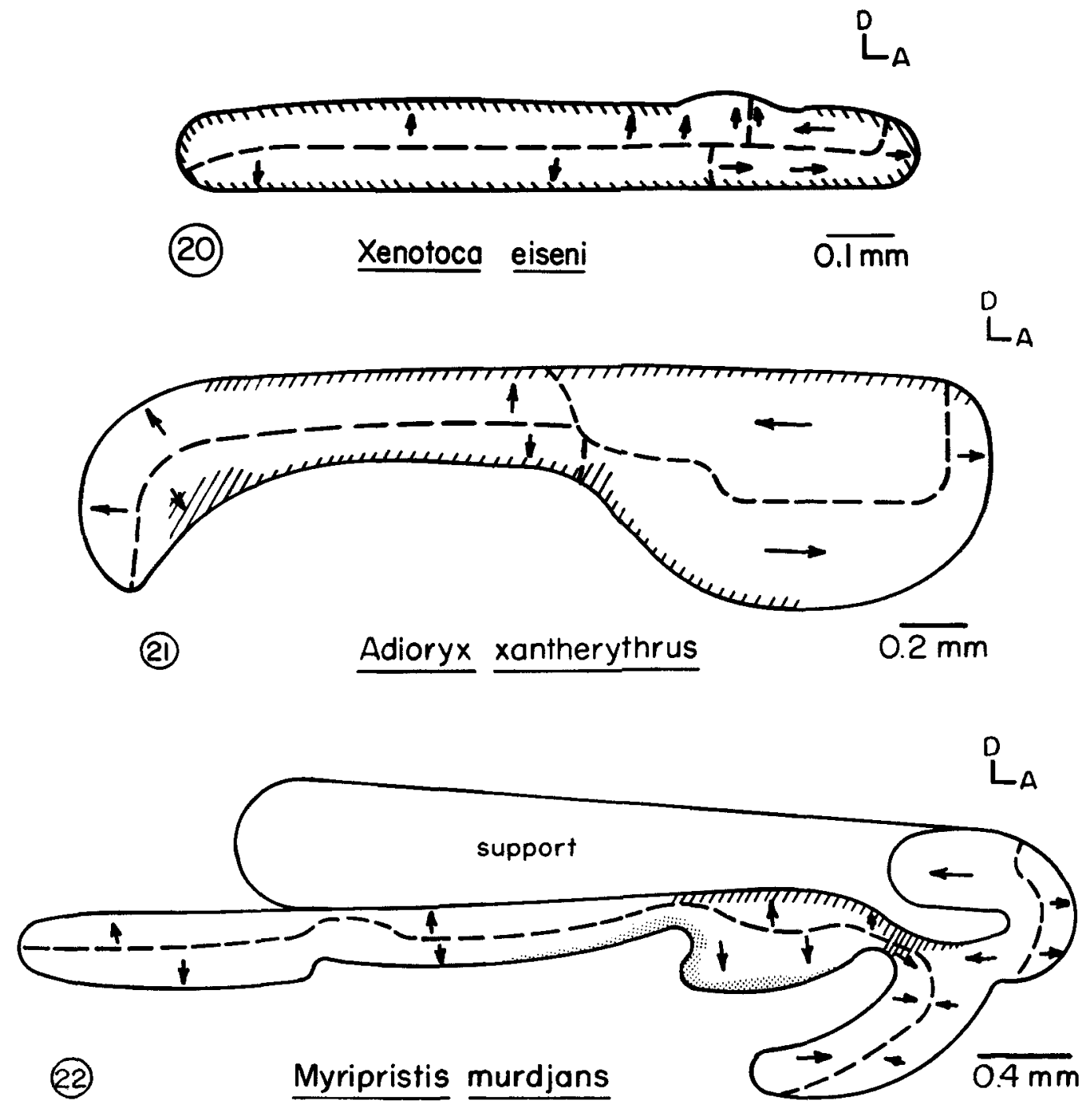

Fig. 20 Saccular macula of Xenotoca. For explanations see figure 4.

Fig. 21 Saccular macula of Adioryx. For explanations see figure 4 .

Fig. 22 Saccular macula of Myripristis. For explanations see figure 4.

However, there is a slight "bulge" on the dorsal-anterior region of the macula - a condition seen in no other species reported here. The saccular otolith covers the posterior $80 \%$ of the macula. Transition from posterior to dorsal cell groups occurs in the bulge region, with transition cells oriented $45^{\circ}$ between the two cell groups.

The type C lagena has marginal F2 ciliary bundles, except in the posterior ventral region. The bulk of the ciliary bundles in the ventral cell group, as well as bundles in both groups located in the dorsal arm, are type F3 while the rest of the dorsal group are type F1.

\section{f. Adioryx (fig. 21)}

This species of squirrelfish (subfamily Holocentrinae) will be treated separately from the related Myripristis since there are significant differences in their sacculus patterns. How- 
ever, lagena patterns are very similar in both species.

The surface of the saccular macula in Adioryx lies parallel to the vertical axis of the fish and the macula is at a $30^{\circ}$ angle to the horizontal plane. Consequently, the anterior end is higher than the posterior. The otolith covers all but the dorsal-anterior region of the macula. The hair cells are arranged in the four basic orientation patterns found in most other species. The anterior group fills the ventral anterior region and anterior tip of the macula. The transition zone between anteriorly and posteriorly oriented hair cells changes direction, much as the ventral margin of the macula curves. Consequently, some of the hair cells in the anterior and posterior cell groups are oriented directly towards one another.

The bulk of the saccular ciliary bundles are type F1 except for marginal F2 cilia. Generally there are one to four rows of $\mathrm{F} 2$ cells.

The lagena in Adioryx is type B with the otolith covering all but the dorsal tip of the macula. The most striking feature of the macula in this species, and in Myripristis, is that the cilia are longer than in the other species studied. The marginal ciliary bundles are similar to type $\mathrm{F} 2$ bundles, while the rest of the macula is covered with what appear to be cells intermediate between types F3 and F4.

\section{g. Myripristis (fig. 22)}

This squirrelfish is a member of the holocentrid subfamily Myripristinae. While the lagenar macula closely resembles that of Adioryx, the saccular macula is significantly different from that in other species studied. The macula is about twice the length of that in Adioryx, although the specimens used were approximately the same standard length. The long axis of the macula is at a $45^{\circ}$ angle to the long axis of the fish's body and its surface lies on the animal's vertical plane. The otolith is triangular shaped, as opposed to the ovoid shape in most other species studied. There is a groove on the otolith not only for the macula outline, but also for the large "support" area extending from the macula.

The posterior portion of the macula has typical type F1 ciliary bundles all the way to the border. The macula becomes thinner about one-third of the way from the posterior end and the dorsal cell region becomes only one or two cells deep for a short distance. The two hair cell groups then become equal in size further anteriorly. Type F3 ciliary bundles start about half-way from the posterior end of the macula and gradually replace the F1 bundles further anteriorly. In this same region bulbous supporting cells (fig. 11) become interspersed among the more typical supporting cells within the sensory area.

Another striking feature of this sacculus is the anterior region which has anterior-oriented cells facing posterior cells and another group of anterior cells at the most anterior region of the macula. The more posterior group of anterior-oriented cell is contiguous with the ventrally-oriented cells.

The enlarged dorsal perimacular region contains supporting cells typical of those in the sensory regions with some bulbous cells interspersed, especially in regions closer to the ventral hair cell regions.

\section{h. Myctophids (figs. 23-25)}

The sacculi in the three species of mesopelagic lanternfishes studied are similar to one another. The sagitta in Ceratoscopelus and Diaphus almost fills the membranous chamber but does not cover the anterior $25 \%$ of the macula. The sagitta in Lampanyctus is as deep as that in the other species, but it does not cover the anterior $50 \%$ of the macula. There is some indication that a cupula-shaped structure that lightly stains with osmium lies over the otolithic membrane anterior to the otolith in all of the species. However, this could not be verified due to the limited number of specimens available.

The saccular macula of each species has the four typical orientation groups. The posterior sacculus has dorsally and ventrally oriented cell groups, while the anterior and posterior groups occupy somewhat different regions than in other species. The posterior orientation group covers the whole anterior end of the macula. The transition zone between anterior and ventral orientation groups is clearly seen in all three species due to the presence of a demarcation line that only contains supporting cells (fig. 27). The demarcation line narrows as it extends anteriorly and it is finally obliterated by hair cells at its anterior end. Preliminary observations indicate that this line marks the separation between two branches of the saccular portion of the eighth nerve, one innervating the region of the macula containing anterior and posterior hair 

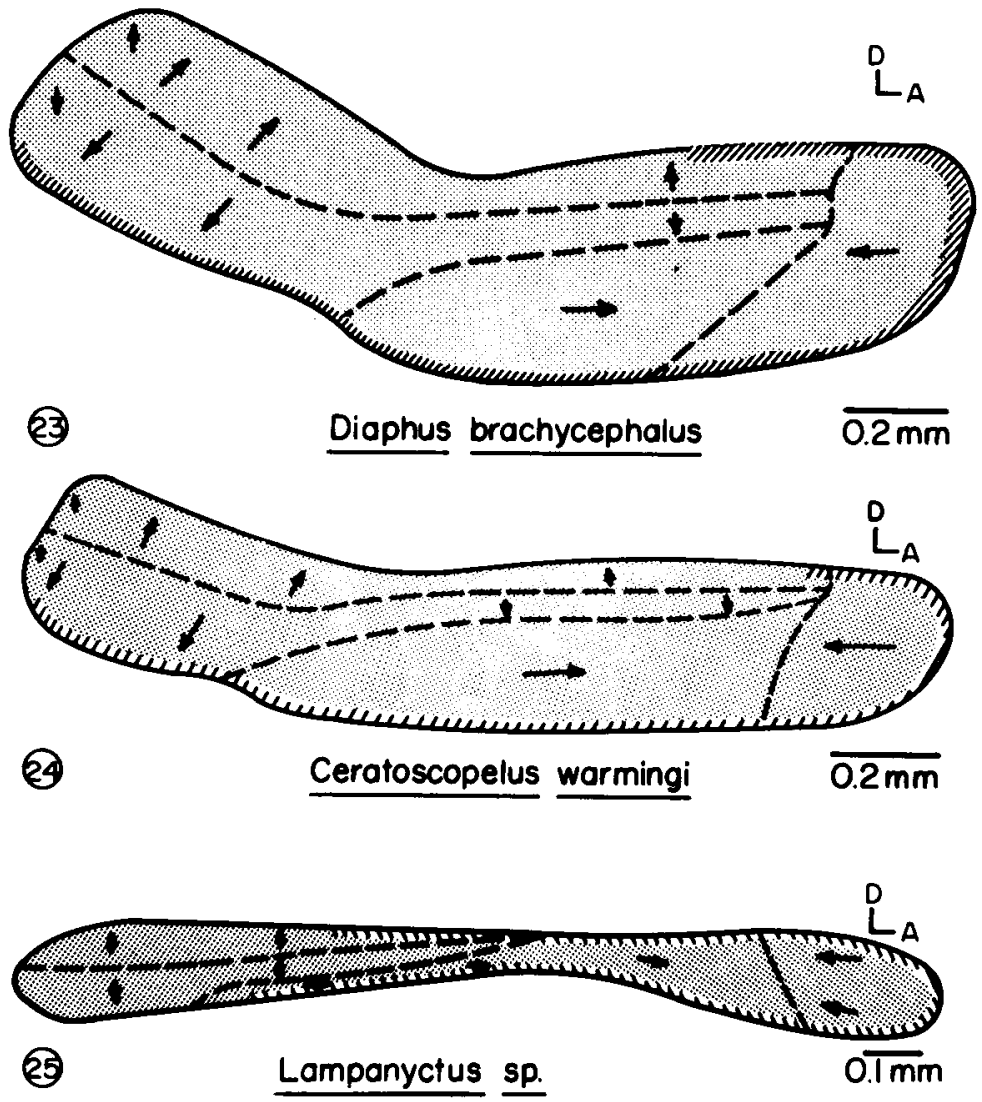

Fig. 23 Saccular macula of Diaphus. For explanations see figure 4.

Fig. 24 Saccular macula of Ceratoscopelus. For explanations see figure 4.

Fig. 25 Saccular macula of Lampanyctus. For explanations see figure 4.

cell groups and one innervating the dorsal and ventral cell group region.

Due to the small size of the lagena in each of these species it was difficult to prepare specimens for study successfully, except in Lampanyctus (fig. 26). Approximately $85 \%$ of the hair cells in this species are oriented ventrally with only a single row of dorsal cells on the margin and a small group in the ventral region. All of the ciliary bundles are type F2 except for some dorsally-oriented cells in the ventral-medial region of the macula which are F3.

In addition to normal hair cells, each of the myctophids has a group of large, square, cells just ventral to the posterior-ventral margin of the saccular macula (fig. 28). There were 13 cells in Lampanyctus and 20 to 30 in the other species (perhaps reflecting size differences in the maculae). Each of the cells has a single long central cilium and an indeterminate number of shorter cilia-like structures. No such cells were found in other species studied.

\section{DISCUSSION}

The data presented here extend earlier work (Dale, '76; Jørgensen, '76; Popper, '76) demonstrating inter-specific variation in the ultrastructure of the sacculus and lagena of teleost fishes. While the variations in hair cell orientation patterns are found in both sacculus and lagena, they are particularly evident in the relationship between the orientation groups on the anterior half of the saccular macula. The posterior half of the saccular macula contains hair cells oriented dorsally and ventrally and this pattern resembles, to a considerable degree, the saccular pattern in 
ostariophysine fishes (e.g., Hama, '69; Jenkins, '74; Platt, '77) and many tetrapods (e.g., Lewis and Li, '73; Lindeman, '69; Spoendlin, '65). The anterior macula region in the 15 non-ostariophysines, as well as in a cod (Dale, '76) and several flatfish (Jørgensen, '76), have horizontally oriented hair cells, a pattern unlike that found in any other vertebrates. The significance of these orientation patterns

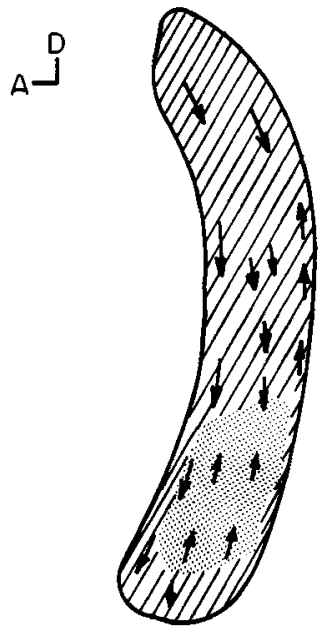

\section{(26) Lampanyctus sp. $0 \overline{0.5 \mathrm{~mm}}$}

Fig. 26 Lagenar macula from Lampanyctus. Note that there is only a small region with dorsally oriented hair cells. For explanations see figure 4. in individual species, as well as the taxonomic and functional significance of the interspecific variation in the morphology and ultrastructure of the teleost ear, is still not known. However, while more extensive ultra. structural and physiological data are neces. sary to enable us to make specific statements on the evolution of the teleost ear and on correlations between structure and function, several suggestions may be made relating to specific patterns of the inner ears in several species as well as to certain very general aspects of inner ear function.

One aspect of inner ear structure and teleost taxonomy that can be considered is the relationship between ear structure and hair cell orientation patterns in the ostariophysine and non-ostariophysine fishes. Each of the non-ostariophysines that has been studied (with the exception of Lota vulgaris, Wersäll et al., '65) has horizontally and vertically oriented hair cells and the sacculus is considerably larger than the lagena in all nonostariophysines species (e.g., von Frisch, '36; Retzius, 1881; Werner, '60). However, there are only vertically oriented hair cells in six ostariophysines (five catfish and one carp) (Hama, '69; Jenkins, '74; Platt, '77) and the lagena is considerably larger than the sac. culus in all Ostariophysi. While more data are needed, especially for the ostariophysines, we might tentatively suggest that the marked differences in inner ear structure between the ostariophysine and non-ostariophysine fishes
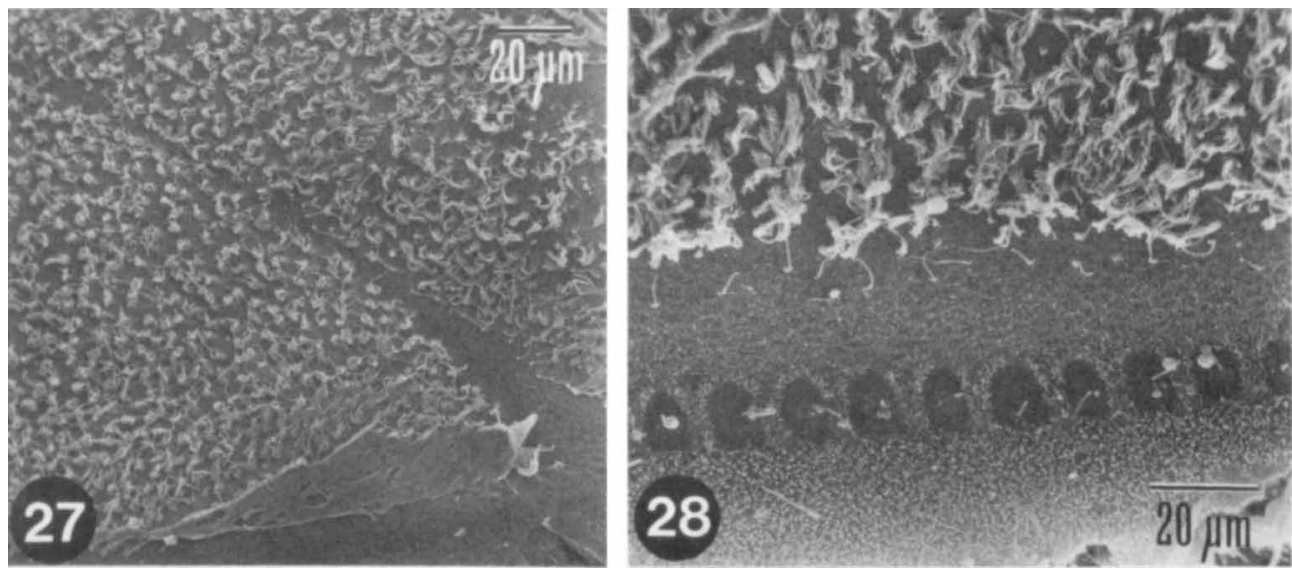

Fig. 27 SEM of the distinct demarcation line found in the three myctophids between the anteriorly oriented hair cells (to the left of the line) and ventrally oriented hair cells (to the right of the line). This line is shown in figures 23 thru 25.

Fig. 28 SEM of series of large cells found in the three species of myctophid. These cells are found just below the ventral-posterior quadrant of the macula. 
indicate significantly separate evolutionary paths for the sacculus and lagena in the two groups. It is possible that the differences are related to the presence of direct acoustic coupling, via the Weberian ossicles, to the swim bladder in the ostariophysines; but without more data on ear structure in species closely related to ostariophysines, this suggestion cannot be tested.

Due to lack of functional data related to hair cell orientation patterns we cannot yet discuss the significance of most inter-specific differences of the sensory maculae. However, several points should be made about the saccular macula patterns in the holocentrids since there are significant differences in the sacculus within this family.

Several aspects of the sacculus in $\mathrm{Myr}$ ipristis are of interest. The saccular otolith is triangular-shaped as compared to the ovoid shape in most of the other species (including Adioryx) I have looked at (although triangular shape appears typical of other members of the same sub-family, Frizzel and Lamber, '61). The shape of the macula itself also differs from that found in any other species of vertebrate with which I am familiar. Finally, the positions of the various orientation groups differ considerably from those in other species. In several macula regions the sensory cells are interspersed with large, atypical, supporting cells, in addition to the more typical cells found in the sensory regions. These enlarged supporting cells are also found in special regions which lie in a dorsal depression on the otolith surface.

The adaptive basis for the different saccular structures in the two holocentrids is not clear and they are especially interesting since the species live sympatrically on Hawaiian reefs and produce similar sounds for communications (Salmon, '67). One suggestion is that the two species have different sound detection capabilities or possibly detect or analyze sounds in different ways. The only data on sound detection capabilities for holocentrids, however, are for species different than those studied here, so only indirect comparisons can be made. Tavolga and Wodinsky ('63) found that Holocentrus ascensionis and Adioryx vexillarus (formerly $H$. vexillarus) have best pure tone auditory sensitivity at $600-800 \mathrm{~Hz}$, although the highest frequency detected by Holocentrus is $2,800 \mathrm{~Hz}$ while it is about $1,200 \mathrm{~Hz}$ for Adioryx. Sensitivity was $10 \mathrm{db}$ better in Holocentrus than in Adioryx. Both species belong to the holocentrid sub-family Holocentrinae, a group without direct contact between the anterior end of the swim bladder and the auditory bulla. However, the anterior region of the swim bladder in species of Holocentrus is closer to the auditory bulla than in Adioryx (Nelson, '55) and from the behavioral data one can conclude that this anterior projection enhances sound detection sensitivity, as has been suggested for other species (Lowenstein, '71; Popper and Fay, '73; Tavolga, '71). Data on sensitivity are not available for Myripristis but this species is a member of the sub-family Myripristinae, a group with swim bladder anterior projections that are in contact with the auditory bulla (see Nelson, '55). We might ex. trapolate from Holocentrus and Adioryx and speculatively suggest that sensitivity in $M y r i$ pristis is enhanced as compared with Adioryx. It is then possible that the sacculus pattern, and general morphology of this otolithic structure in Myripristis, is in some way correlated with the differences in swim bladder inner ear relationships or, perhaps, the gen eral role of the swim bladder as a participant in sound detection in some species and not in others (see Fay and Popper, '74, '75).

\section{Ciliary bundles}

A number of different ciliary bundles have been found on the hair cells in teleosts. It is necessary to point out, however, that the four types reported here are essentially only points on a continuum and that intermediary forms were often observed. Similar observations on gradation between six types of ciliary bundles were reported in several amphibians (Lewis and $\mathrm{Li}$, '75; Lewis and Neminac, '72); and Dale ('76) has observed various types in Gadus but has chosen to consider all of these a continuum of a single type of ciliary bundle. In fishes, as in amphibians, and lampreys (Hoshino, '75; Lewis and Li, '75) the different ciliary bundles are found in relatively discrete macular regions and these regions may include cells from several orientation groups. The presence of different types of ciliary bundles, and their location in specific areas, suggests a potential functional correlate for the different bundle types.

Comparisons of hair cell ciliary bundle types can only be made with one other teleost species, Gadus morhua (Dale, '76). Dale has reported ciliary bundles that resemble the types $F 1$ and F2 found in the species I have studied, and he also reports lagena ciliary 
bundles that more nearly resemble the bundles found on the lagena in both holocentrids, rather than the cells found in other species. Some comparisons can also be made with data for the Japanese lamprey, Entosphenus japonicus, which has two types of ciliary bundles (Hoshino, '75) as does Lampetra fluviatilis (Lowenstein et al., '68). Hoshino ('75) found one bundle, designated type $\mathrm{A}$, that resembles the teleost F2 bundle. The lamprey type B bundle has a long kinocilium and shorter, nongraded, stereocilia. While the general F2 form in teleosts has short but graded stereocilia, I did, at times, see stereocilia that appeared to be equal in height in some salmonids. While preliminary, these data indicate that similar ciliary bundles are to be found throughout the aquatic anamniotes.

The most extensively described ciliary bundles have been the six types found in the bullfrog, Rana catesbeiana (Lewis and Li, '75). Some of the types in Rana resemble those in teleosts. Most notably, Lewis and Li found one bundle (their type F) which closely resembles the teleost F3 bundle, while another (type B) is similar to the teleost type F2. While no frog ciliary bundle fully resembles the teleost $\mathrm{F} 1$ bundles, the type $E$ has short graded stereocilia with a slightly longer kinocilium. However, the kinocilium on this frog cell has a bulbous ending. Similar endings are found in other frog hair cells, as well as in several reptile cells (Bägger-Sjöbäck, '74) but have yet to be reported for fishes (see also Dale, '76; Platt, '77).

Several generalizations about distribution of the various ciliary bundles in fishes may be made, but these must be qualified since there is considerable variation in the different species studied. In general, the type F1 bundle makes up the dominant cell on the sacculus in all species except the myctophids where the dominant bundle is F3. The type F2 bundle is most often found on macula margins. The type F3 ciliary bundle is the pattern most often found in macula areas not directly covered by the otolith, but this is not always the case, as seen in myctophids where the whole saccular macula has F3 bundles.

The functional or structural significance of each of the ciliary patterns remains to be determined. Lewis and $\mathrm{Li}$ ('75) suggest that structure could reflect differences in stages of morphogenesis, or in relationships to overlying structures (otolith and/or otolithic membrane), or differences in stimulation mecha- nisms or sensitivity. Considering differences in morphogenesis, Lewis and $\mathrm{Li}$ ('75) point out that their type A bundle, which somewhat resembles the teleost F2 ciliary bundles, is of ten found on the edges of the saccular macula, an area that they have identified as one of growth for that organ (Lewis and $\mathrm{Li}$, '73; also see Corwin, '77). The type F2 ciliary bundles, are also found peripherally and while nothing is yet known about morphogenesis of the teleost otolithic organs, F2 cells "grade" into type F1 cells in the more central areas of the maculae (fig. 9).

\section{Functional significance of inner ear structure}

The complex structure and orientation patterns of the teleost sacculus and lagena lead to the conclusion that these organs may be highly adapted for signal detection and processing and that these functions may vary in different species. However, due to the paucity of data it is still essentially impossible to speculate on the functional significance of the variation observed in the 15 species reported here. Considering the morphology and ultrastructure of the sacculus and lagena in general, however, we can suggest that the ear may be adapted for providing some complex types of signal analysis (i.e., frequency or intensity discrimination) or in some species, for providing the animals with information for determining the direction of a sound source in the space around the animal.

Several workers have suggested that the otolith and macula may move in different patterns relative to one another in response to signals that differ in frequency or intensity (van Bergeijk, '67b; Popper and Clarke, '76; Sand, '74). As a result, different hair cell regions would respond to different signals, thus providing for some degree of signal analysis at the level of the inner ear. The movement patterns of the otoliths and maculae would possibly be "enhanced" by the complex shapes of these structures, and the interspecific variation in the otoliths and the maculae would then be responsible for differences in detection capabilities or signal analysis by different species. While it is not yet possible to predict the specific nature of the movements, a possible basis for variation in response on the saccular macula in many species is likely to be coupling of different hair cell groups to the otolith. In many species reported here some portions of the saccular 
macula are directly covered by the sagitta while other regions are only overlain by the thin otolithic membrane. Consequently, coupling of otolith movement to the cells in contact with the otolith, and those only covered by the otolithic membrane, would be sig. nificantly different. This would result in different hair cell stimulation across the saccular macula. Evidence for such regional variation due to direct and indirect coupling to the otolith is not yet available for fishes. However, an analogous system does occur in the basilar papilla of the alligator lizard (Ger. rhontous multicainatus) where different physiological responses have been recorded from neurons innervating different regions of the basilar papilla (Weiss et al., '76). These workers suggest that the response differences are related to anatomical findings that hair cells in one portion of the basilar papilla are in contact with the tectorial membrane, while cells in another region of the basilar papilla are not in contact with the membrane.

The structural adaptations of the inner ear may also have evolved to function in determining the direction of a sound source as a prelude to actually approaching the source (sound localization). A number of workers have recently provided evidence that the inner ear may be involved in sound orientation in some teleost species (Enger et al., '73; Moulton and Dixon, '67; Sand, '74; Schuijf, '75; Schuijf and Buwalda, '75). Particularly important are data showing that the levels of microphonic response from different regions of the saccular macula vary as a function of stimulus direction (Enger et al., '73; Sand, '74). These directional responses are closely correlated with data on orientation patterns of hair cells in various macular regions (also see Dale, '76), suggesting that the different microphonic responses represent stimulation of hair cells that are oriented in different directions.

The amount of directional information available to fishes is potentially more extensive than just from four discrete orientation groups. Of particular importance are the graded responses for the hair cells (Flock, '65, '71; Harris and Van Bergeijk, '62; Schwartz, '67). Schwartz ('67) has proposed that two hair cells, oriented at $90^{\circ}$ to one another, can provide precise two-dimensional directional information (also see van Bergeijk, '64) if the level of response of the two cells can be compared at some level in the CNS, perhaps in a fashion analogous to that proposed for mam. malian localization by van Bergeijk ('62), Hall ('65), Erulkar ('72) and others. Further, by adding a third receptor (or group of receptors) oriented $90^{\circ}$ from the first two, an animal could tell sound direction in three dimensions (van Bergeijk, '64). Thus, if information in afferent fibers from different orientation groups are kept separate to a level of some comparator, then a single teleost sacculus would provide sufficient information in two dimensions. Three-dimensional information would be derived from two ears oriented in different directions as well as by the curvature of the maculae (both sacculus and lagena), since this produces cells oriented in different directions even within the four major orientation groups.

Finally, it is necessary to note that the hy. pothesis proposed here for determination of sound source direction has several limitations. One limitation is that this system would not permit discrimination of signals that are $180^{\circ}$ apart. Consequently, fishes would theoretically have difficulty telling "front from back" (Schuijf, '75; Schuijf and Buwalda, '75). A second limitation is that the proposed hypothesis may only be applicable to species not using the swim bladder for sound detection or, in certain instances where the swim bladder is used but where it is not directly coupled to the ear. Species, such as the Ostariophysi, having both ears stimulated by a single swim bladder, lose any directional information about the impinging signals. However, in non-ostariophysines the swim bladder could respond directionally to displacement signals and then set up a sound field which would be used to provide directional stimulation to the ear. Consequently, it is possible that stimulation by bone conduction, or with the swim bladder, could result in detection of sound direction.

\section{ACKNOWLEDGMENTS}

This work was done while I was in residence at the Kresge Hearing Research Institute and the Division of Biological Sciences, University of Michigan. I would like to express my sincerest thanks to Doctor J. E. Hawkins, Jr., for providing me with laboratory facilities and for valued discussions during the course of this work. I would also like to express my appreciation to $R$. Preston for invaluable help in all phases of this investigation. Doctor $L$. R. Aronson and J. Taylor kindly supplied me 
with several species used in this study. Additional animals were provided by the Great Lakes Fisheries Laboratory of the U. S. Fish and Wildlife Service and my particular thanks to Doctors R. Reinert and D. Rottiers for their assistance. Ms. N. Clarke served gallantly in collecting the deep sea species and preparing them for study while on a rolling ship. The staff of the University of Michigan Scanning Electron Microscopy-Electron Microprobe Analysis Laboratory provided invaluable help in all phases of the SEM work. I would also like to thank J. Corwin for suggesting the use of the ultrasonic cleaner, J. Bruce for doing the many illustrations, and the staff of the Kresge Hearing Research Institute photographic shop for considerable assistance. Doctors W, C. Stebbins and W. N. Tavolga kindly read and commented upon the manuscript.

Work was supported by Public Health Service grants from the National Institute of Neurological and Communicative Disorders and Stroke, NS-09374 to A. N. Popper and NS05065 and NS-05679 to J. E. Hawkins, Jr.; by Program Project Grant NS-05785 to M. Lawrence, and by a biomedical science support grant from the University of Hawaii to A. N. Popper.

\section{LITERATURE CITED}

Bägger-Sjobäck, D. 1974 The sensory hairs and their attachments in the lizard basilar papilla. Brain, Behav. and Evol., 10: 88.94.

Békésy, G. von 1960 Experiments in Hearing. McGrawHill, New York, 745 pp.

Bereijk, W. A. von 1962 Variations on a theme of Bekesy: a model of binaural interaction. J. Acoust. Soc. Amer., 34: 1431-1437.

- 1964 Directional and non-directional hearing in fish. In: Marine Bio-Acoustics. W. N. Tavolga, ed. Pergamon Press, Oxford, pp. 281-300.

- 1967a The evolution of vertebrate hearing. In: Contributions to Sensory Physiology. W. D. Neff, ed. Academic Press, New York, pp. 1-49.

1967b Discussion. In: Marine Bio-Acoustics. Vol. 2. W. N. Tavolga, ed. Pergamon Press, New York, p. 244 .

Caldwell. D. K., and M. C. Caldwell 1963 Underwater sounds associated with aggressive behavior in defense of territory by the pinfish, Lagodon rhomboides. Bull. So. Calif. Acad. Sci., 66: 69-75.

Corwin, J.T. 1977 Morphology of the macula neglecta in sharks of the genus Carcharhinus. J. Morph., 152: 341362 .

Dale, T. 1976 The labyrinthine mechanoreceptor organs of the cod, Gadus morhua L. (Teleostei: Gadidae) Norw. J. Zool., 24: 85-128.

Enger, P. S. 1963 Single unit activity in the peripheral auditory system of a teleost fish. Acta. Physiol. Scand. (Suppl.), 59: 210 .
1973 Masking of auditory responses in the medulla oblongata of goldfish. J. Exp. Biol., 59: $415 \cdot 424$

Enger, P. S., A. D. Hawkins, O. Sand and C. J. Chapman 1973 Directional sensitivity of saccular microphonic potentials in the haddock. J. Exp. Biol., 59: 425-433.

Erulkar, S. D. 1972 Comparative aspects of spatial localization of sound. Physiol. Rev., 52: 237-360.

Fay, R. R. 1975 Sound reception and processing in the carp: saccular potentials. Comp. Biochem. Physiol., 49A: 29-42.

Fay, R. R., and A. N. Popper 1974 Acoustic stimulation of the ear of the goldfish. J. Exp. Biol., 61: 243-260.

1975 Modes of stimulation of the teleost ear. J. Exp. Biol., 62: 379-388.

Flock, A. 1965 Electron microscope and electrophysiological studies of the lateral-line canal organ. Acta OtoLaryngol. (Suppl.), 199: 1-90.

- 1971 Sensory transduction in hair cells. In: Handbook of Sensory Physiology. Vol. 1. W. R. Lowenstein, ed. Springer-Verlag, Berlin, Heidelberg, New York, pp. 396-411.

Frisch, K. von 1936 Über den Gehörsinn der Fische. Biol. Rev., 11: 210-246.

Frizzell, D. L, and C. K. Lamber 1961 New genera and species of myripristid fishes in the gulf coast Cenozoic, known form otoliths (Pisces, Beryciformes). Bull. U. Missouri School Mines and Metallurgy, No. 100, pp. 3-25.

Furukawa, T., and Y. Ishii 1967 Neurophysiological studies on hearing in goldfish. J. Neurophysiol., 30: 1377 . 1403.

Gerald, W. 1971 Sound production during courtship in six species of sunfish (Centrachidae). Evol., 25: 75-87.

Hall, J. L. 1965 Binaural interaction in the accessory superior olivary nucleus of the cat. J. Acoust. Soc. Amer., 37: 814-823.

Hama, K. 1969 A study on the fine structure of the saccular macula of the goldfish. Z. Zellforsch., 94: 155-171.

Harris, G. G., and W. A. van Bergeijk 1962 Evidence that the lateral organ responds to near-field displacements of sound sources in water. J. Acoust. Soc. Amer., 34: 18311841.

Hoshino, T. 1975 An electron microscopic study of the otolithic maculae of the lamprey (Entosphenus japonicus). Acta Oto-Laryngol., 80: 45-53.

Jenkins, D. B. 1974 A preliminary report on anatomical studies of the inner ear in catfishes (Siluriformes). Anat. Rec., 78: 382.

Jorgensen, J. M. 1976 Hair cell polarization in the flatfish inner ear. Acta Zool. (Stockholm), 57; 37-39.

Lewis, E. R., and C. W. Li 1973 Evidence concerning the morphogenesis of saccular receptors in the bullfrog (Rana catesbeiana). J. Morph., 139: 351-362.

- 1975 Hair cell types and distribution in the otolithic and auditory organ of the bullfrog. Brain Res, 83: $35-50$.

Lewis, E. R., and P. Nemanic 1972 Scanning electron mi. croscope observations of saccular ultrastructure in the mudpuppy (Necturus maculosus). Z. Zellforsch., 123. 441-457.

Lindeman, H. H. 1969 Regional differences in structure of the vestibular sensory regions. J. Laryngol. Otol., 83: 1 - 17.

Lowenstein, O. 1971 The labyrinth. In: Fish Physiology. Vol. 5. W. S. Hoar and D. J. Randell, eds. Academic Press, New York, pp. 207.240.

Lowenstein, O., M. P. Osborne and R. A. Thornhill 1968 The anatomy ultrastructure of the labyrinth of the lamprey (Lampetra fuviatilis L.). Proc. Roy. Soc. Lond. B., $170: 113 \cdot 134$. 
Lowenstein, O., M. P. Osborne and J. Wersäll 1964 Structure and innervation of the sensory epithelia of the labyrinth in the thornback ray (Rqja clavata). Proc. Roy. Soc. Lond. B, 160: 1-12.

Lowenstein, O., and J. Wersäll 1959 A functional interpretation of the electron-microscopic structure of the sensory hairs in the cristae of the elasmobranch Raja clavata in terms of directional sensitivity. Nature, 184 . 1807-1808.

Marshall, N. B. 1967 Sound-producing mechanisms and the biology of deep-sea fishes. In: Marine Bio-Acoustics. Vol. 2. W. N. Tavolga, ed. Pergamon Press, New York, pp. 123.134.

Masterton, R. B. 1974 Adaptation for sound localization in the ear and brainstem of mammals. Fed. Proc., 33 1904-1907.

Miller, M. 1974 Scanning electron microscopy of the lizard papilla basilaris. Brain, Behav. and Evol., 10: 95-112.

Moulton, J. M., and R. H. Dixon 1967 Directional hearing in fishes. In: Marine Bio-Acoustics. Vol. 2. W. N. Tavolga, ed. Pergamon Press, pp. 187-232.

Myrberg, R., Jr., E. Kramer and P. Heinecke 1965 Sound production by cichlid fishes. Science, 149: 555-558.

Myrberg, R., Jr., and J. Y. Spires 1972 Sound discrimination by the bicolor damselfish, Eupomacentrus partitus. J. Exp. Biol., 57: 727-735.

Nelson, E. M. 1955 The morphology of the swim bladder and auditory bulla in the Holocentridae. Fieldiana: Zool. 37: $121-130$

Piddington, R. W. 1972 Auditory discrimination between compressions and rarefactions by goldfish. J. Exp. Biol., 56: 403-419.

Platt, C. 1977 Hair cell distribution and orientation in goldfish otolith organs. J. Comp. Neur., 172: 283.298.

Popper, A. N. 1976 Ultrastructure of the auditory regions in the ear of the lake whitefish. Science, 192: 1020-1022.

Popper, A. N., and N. L. Clarke 1976 The auditory system of the goldfish (Carassius auratus): effects of intense acoustic stimulation. Comp. Biochem. Physiol., 53A: 11-18

Popper, A. N., and R. R. Fay 1973 Sound detection and processing by fish: A critical review. J. Acoust. Soc. Amer., 53: 1515-1529.

Popper, A. N., M. Salmon and A. Parvulescu 1973 Sound localization by the Hawaiian squirrelfishes Myripristis berndti and $M$. argyromus. Anim. Behav., 21: 86-97.
Retzius, G. 1881 Das Gehörorgan der Wirbelthiere. Vol 1. Samson and Wallin, Stockholm.

Saito, K. 1973 Fine structure of the macula of lagena in the teleost inner ear. Acta Anat. Nipponica, 48:1-18.

Salmon, M. 1967 Acoustical behavior of the menpachi, Myripristis berndti, in Hawaii. Pacific Science, 21: 364381.

Sand, O. 1974 Directional sensitivity of microphonic potentials from the perch ear. J. Exp. Biol., 60: 881-899.

Schuijf, A. 1975 Directional hearing of cod (Gadus morhua) under approximate free field conditions. J. Comp. Physiol., 98: 307-332.

Schuijf, A., and R. J. A. Buwalda 1975 On the mechanism of directional hearing in the cod (Gadus morhua L.). J. Comp. Physiol., 98: 333-343.

Schwartz, E. 1967 Analysis of surface wave perception in some teleosts. In: Lateral-Line Detectors. P. H. Cahn, ed. Indiana University Press, Bloomington, pp. 123-134.

Spoendlin, H. 1965 Ultrastructural studies of the labyrinth in squirrel monkeys. In: The Role of the Vestibular Organ in the Exploration of Space. NASA Sp., 77: 7-22.

Tavolga, W. N. 1971 Sound production and detection. In: Fish Physiology. Vol. 5. W.S. Hoar and D. J. Randell, eds. Academic Press, New York, pp. 135-205.

- 1974 Signal/noise ratio and the critical band in fishes. J. Acoust. Soc., 55: 1323-1333.

Tavolga, W. N., and J. Wodinsky 1963 Auditory capacities in fishes: pure tone thresholds in nine species of marine teleosts. Bull. Amer. Mus. Nat. Hist., 126: 177-240.

Van der Walker, J. 1967 Response of salmon to low frequency sound. In: Marine Bioacoustics. Vol. 2. W. N. Tavolga, ed. Pergamon Press, Oxford, pp. 45-58.

Weiss, T. F., M. J. Mulroy, R. G. Turner and C. A. Pike 1976 Tuning of single fibers in the cochlear nerve of the alligator lizard: Relation to receptor morphology. Brain Res., 115: 71-90.

Werner, Cl. F. 1960 Das Gehörorgan der Wirbeltiere und des Menschen. G. Thieme, Leipzig.

Wersäll, J. A., A. Flock and P. G. Lundquist 1965 Structural basis for directional sensitivity in cochlear and vestibular receptors. Cold Spring Harbor Symp. Quant. Biol., 30: 115-132.

Wever, E. G. 1969 Cochlear stimulation and Lempert's mobilization theory. Arch. Otolaryngol., 90:68-73.

1971 The mechanics of hair.cell stimulation. Ann. Otol. Rhinol. Laryngol., 80: 786-804. 